DOI:10.32703/2617-9040-2021-37-19

UDC 656.11

Ivan Kulbovskyi ${ }^{1}$, Halyna Holub ${ }^{2 *}$,Viktor Melenchuk ${ }^{3}$, Viktor Chmyr ${ }^{4}$

1 Department of automation and computer-integrated transport technologies, State University of Infrastructure and Technologies, srt. Kyrylivska, 9, Kyiv, 04071, Ukraine. ORCID: http://orcid.org/0000-00025329-3842

2 Department of automation and computer-integrated transport technologies, State University of Infrastructure and Technologies, str. Kyrylivska, 9, Kyiv, 04071, Ukraine. ORCID: http://orcid.org/0000-00024028-1025

${ }^{3}$ Department of repair and operation of automotive and special equipment, Military Academy, str. Fontanskaya road, 10, Odessa, 65009, Ukraine. ORCID: https://orcid.org/0000-0003-1236-6731

${ }^{4}$ Department of Vehicles and Special Equipment, National Academy of the State Border Guard Service of Ukraine named after Bohdan Khmelnytsky, str. Shevchenko, 46, Khmelnytsky, 29000, Ukraine. ORCID: https://orcid.org/0000-0002-0465-2589

*Corresponding author: golub_gm@gsuite.duit.edu.ua

\title{
DEVELOPMENT OF A SYSTEM MODEL OF TECHNICAL OPERATION MANAGEMENT IN TRANSPORT INFRASTRUCTURE PROJECTS
}

The article considers the problems of quality management of repair and operation of technical means in projects of development and maintenance of transport infrastructure, which is the most important factor in improving living standards, economic, social and environmental safety. The project quality management system and planning methodology are considered. It is investigated that in order to improve this system it is necessary to solve the problem of integration of quality management principles and their adaptation to transport infrastructure projects on quality management of repair and operation of technical means and the ways of solution are shown.

A set of interrelated organizational and technological tasks and measures aimed at restoring the normative transport and operational indicators of repair and operation of technical means of transport is considered.

It is investigated that the process of project quality assurance at the level of quality management in transport infrastructure projects consists of the adoption of planned systematic measures to ensure the implementation of all envisaged processes. On the basis of researches the system model of criteria by means of which it is possible to define system efficiency of development and realization of the corresponding projects of transport infrastructure is offered.

As a result of solving this problem, a model of management and decision support for diagnostics of technical means in transport infrastructure projects has been developed, which opens prospects for planning and timely maintenance and repair of technical means of transport to ensure and improve traffic safety.

Keywords: technical means, model, control system, monitoring, project, quality, system analysis.

Introduction. In today's market there is an increased interest in the issue of project management quality. Increased interest in quality management of repair and operation of technical means in projects of development and maintenance of transport infrastructure is the most important factor in improving living standards, economic, social and environmental safety. It is almost impossible to solve this problem only by controlling the system, ie by traditional methods. 
There should be a comprehensive, systematic approach, the implementation of which is possible only within the management system based on systems analysis, namely the development of strategy and organization of the technological process of operation of technical means [1].

Analysis of recent research and problem statement. One of the key issues in the development of quality management of repair and operation of technical means in projects of development and maintenance of transport infrastructure of Ukraine is project activity. Accordingly, the relevance of the study of integration issues of quality management, as well as the methodology of organization, planning, management, coordination of human, financial and logistical resources during the life cycle, which aims to effectively achieve the project goal and defined results in terms of composition and scope of work, their cost, sometimes, quality through the application of modern methods of management technologies [2].

The most important parameter of the project, which can and should be managed is its quality, and quality management involves the processes necessary to meet the needs for which it is designed, as well as the quality and products of the project [3]. Examining the project quality management system and planning methodology, the problem of integration of quality management principles and their adaptation to transport infrastructure projects for quality management of repair and operation of technical means remains relevant, which requires further systematic research.

The purpose and tasks of the study. The purpose of the study is to form a system model for ensuring the quality of design work during operation, repair and maintenance of technical means of transport.

Objectives of the study: 1 . To analyze the problems of quality management of repair and operation of technical means in projects of development and maintenance of transport infrastructure. 2. Investigate a set of technological tasks and measures that are necessary to ensure the operation of technical means in transport infrastructure projects. 3. Define procedures for the implementation of transport infrastructure projects for the operation of technical means of transport. 4. Develop a system model for managing the operation of technical means of transport.

Materials and methods of research. Recently, quality management is perceived in its final form as the final product. However, the problem of improving the quality of products and services is so complex and diverse that its successful solution is possible only if all participants in the production and technological process of repair and operation of technical means not only care about the pragmatic side of this case, but also form a modern system of views. , will improve the system and quality management, will develop the planning methodology in infrastructure projects [4].

Quality in modern economic conditions is an integral target characteristic of each project product. Without compliance with the planned parameters, quality standards of the project object it is impossible to achieve the goal.

Under the project management we will consider a set of interrelated organizational and technological tasks and measures aimed at restoring the normative transport and operational indicators of repair and operation of technical means of transport and carried out under financial and other resource constraints in a timely manner. The main reason for the development and implementation of projects for the operation of technical means of transport is non-compliance with regulatory indicators.

Within project management, there are two types of processes, the first of which are management processes that are common regardless of the type of project, aimed at achieving a common goal and include such groups of processes as initiation, planning, implementation, monitoring and management and completion. The second type of process is a product-oriented 
process and consists in determining the main properties, characteristics and purpose of the product, with the subsequent implementation of this complex in reality, in accordance with the interests of all stakeholders in creating a project product. Good project management, aimed at both groups of processes, is not enough to succeed. The key to success is a detailed, specific, measurable quality criterion for managing all types of project processes [5]. Therefore, there is a need to integrate quality management in the management of all types of processes, which will meet the requirements of the customer not only the quality of the final product of the project, but also its quality functional system.

The main parameter of the project quality is the quality of the product, namely the transportation of passengers, goods, which is the result of execution. The quality of a product or service is often understood as a set of its properties that determine the level of ability to meet certain needs of consumers in accordance with their purpose.

In the management of the quality of operation and repair of technical means in transport infrastructure projects, the concept of «quality» is considered in four aspects [6]:

1) product quality as compliance with market needs and consumer expectations, which is achieved through accurate and effective identification of customer needs and expectations in order to meet them;

2) the quality of development and planning, which is achieved through detailed and careful development of the project and its product;

3 ) the quality of work on the project in accordance with the planning documentation, which is ensured by compliance with the implementation of its plan, as well as ensuring the developed characteristics of the product and the project itself;

4) the quality of resources involved in the implementation of the project and is achieved through high-quality logistics of the project throughout its life cycle.

The quality assurance process at the level of quality management in transport infrastructure projects consists of the adoption of planned systematic measures to ensure the implementation of all envisaged processes necessary for the project to meet quality requirements.

The planning methodology is the most important factor influencing the quality of the project and includes the following stages:

1. Definition of goals and their description. Quite often projects start without a clear goal.

2. Definition of technological stages. Implementation technology must be selected for the project, which determines the stages of development. One of the typical planning mistakes is the inconsistency of the technological cycle plan.

3. For technological stages it is necessary to define the list of tasks, to specify their interrelation, sequence and the forecasted duration.

4. The need to agree on the resources allocated to the project. It should be noted that all resources of the organization should be distributed centrally. Quite often there is a planning error due to the fact that some scarce resources are used simultaneously in two different projects at the same time.

5. Analysis and assessment of risks lead to the emergence of new tasks and to attract additional resources.

6. Determining the price of resources determines the budget. One of the common mistakes is that the budget is set without paying attention to the projected cost of the project.

The formation of a quality assurance plan should be based on a systematic approach. The quality management process is a component of any project planning.

Quality assurance involves defining a standard, appropriate methods and quality requirements. The integration of the requirements of ISO 10006: 2005 and PMBOK [7] makes it possible to 
form a logical set of quality assurance measures, which can be presented in the form of a quality assurance plan. Thus, the quality of the final result can be influenced by the method of influencing its forming processes. All processes are elements of the system in which they operate. The quality of construction of this system and the mechanism of its functioning affects the quality of its components.

Transport infrastructure projects for the operation of technical means of transport are not typical and are implemented according to a certain procedure. Quality parameters and the process of its provision should be formed for each project separately. The task of ensuring the quality of the project at the appropriate level is relevant at all stages of its life cycle and is implemented by various procedures that are interrelated [8].

In order to ensure compliance of the achieved results of the project with the previously established indicators, it is necessary to implement quality management through the following processes: planning, quality assurance and control [9].

Quality planning is carried out as part of project planning, which must include work, the implementation of which ensures the quality of results. The quality plan should determine how the project will ensure the quality of work from the standpoint of organizational structure, resources, technological support. An important element, at the stage of quality planning, is the development of documents governing actions for quality control of project management and quality management procedures. Quality planning begins with defining quality objectives, policies and standards related to the content of the project. The actions and responsibilities of the team members, which are necessary to achieve the goals and adhere to the standards, are then determined. The result of quality planning $[10,11]$ is presented in the form of quality assurance plans and management processes that ensure the implementation of these plans, and is achieved by synchronization with the main (content planning, schedule, cost) and auxiliary (risk planning, team) planning processes.

Quality assurance is carried out through the process of performing planned systematic operations on quality management, which ensure the implementation of all the envisaged processes necessary for the project to meet the established quality requirements. To control the quality of the project, it is necessary to define control points and criteria, to determine the compliance of project quality with the standards set in the quality assurance plan. The knowledge and experience of quality assurance gained in the current project should be used in drawing up quality assurance plans for subsequent projects.

The system model of criteria of management of operation of technical means thanks to which it is possible to define system efficiency of development and realization of the corresponding projects of transport infrastructure of improvement of management of quality of repair and maintenance of technical means of transport is presented. The system model of quality of design works at operation, repair and the maintenance of technical means of transport is the following:

$$
\begin{gathered}
A=\left(\frac{\int_{0}^{T} \phi_{1}\left(i, G_{1}, \overline{G_{1}}\right)\left|G_{1}(i)-\overline{G_{1}}(i)\right| d i}{\int_{0}^{T} \overline{G_{1}}(i) d i}\right) \\
G_{i}=G_{1 i}, i=1,2, \ldots, N,
\end{gathered}
$$

where $G_{i}-$ value that characterizes the production and technological potential in transport infrastructure projects in the i-th period of time; 
$G_{1 i}$ - useful work performed by transport infrastructure units for operation and repair of technical means in the i-th period of time.

$$
\begin{gathered}
G_{1 i}=\left(\sum_{j=1}^{M} \sum_{i=1}^{N} h_{j i} L_{j i}\right)\left(1+r_{i}\right)+\left(\sum_{k=1}^{K} a_{k} c_{k} q_{k}\right)\left(1+r_{i}\right)+\left(\sum_{j=1}^{M} b_{j} \tilde{c}_{j} \tilde{q}_{j}\right)\left(1+r_{i}\right)+\left(\sum_{i=1}^{N} \sum_{p=1}^{P} c_{1 i p} Q_{i p}\right) * \\
*\left(1+r_{i}\right)=\left(1+r_{i}\right)\left(\sum_{j=1}^{M} \sum_{i=1}^{N} h_{j i} L_{j i}+\sum_{k=1}^{K} a_{k} c_{k} q_{k}+\sum_{j=1}^{M} b_{j} \tilde{c}_{j} \tilde{q}_{j}+\sum_{i=1}^{N} \sum_{p=1}^{P} c_{1 i p} Q_{i p}\right) \\
i=1,2, \ldots, M ; i=1,2, \ldots, N ; k=1,2, \ldots, K ; p=1,2, \ldots, P
\end{gathered}
$$

where $r_{i}$ - the set level of profitability of functioning of technological processes of operation and repair of technical means of transport on the $\mathrm{i}$-th period of time $\left(\mathrm{O}<r_{i}<1\right)$; .

$c_{1 i p}$ - the cost of the service provided to the $\mathrm{p}$-name for the $\mathrm{i}$-th period of time;

$Q_{i p}$-number of services provided and performance of works in the environment of functioning of technological processes on repair and operation on the i-th period of time.

$$
h_{j i}=h_{z i j} k_{z i}+h_{M j} k_{M i}+h_{z r j} k_{z r i}+h_{e i j} k_{e i}+h_{T i j} k_{T i}+h_{C T i j} k_{C T i}
$$

where $h_{z i j}, h_{M j}, h_{z r j}$ - according to the standards of wage costs, materials, spare parts for the mechanisms of the $\mathrm{j}$-th name in the base period;

$k_{z i}, k_{M i}, k_{z r i}$ - respectively, the index of growth of costs for wages, materials, spare parts for the $\mathrm{i}$-th period of time;

$h_{e i j}, h_{T i j}, h_{C T i j}-$ respectively, the standards of costs for electricity, heat and compressed air in the base period;

$k_{e i}, k_{T i}, k_{C T i}$ - respectively, the growth indices of regulatory costs for electricity, heat and compressed air in the i-th period of time.

$$
\begin{aligned}
& \left.A_{i}=\left|G_{1 i}-\overline{G_{1 i}}\right|, \text { for } G_{1 i}\right\rangle \overline{G_{1 i}}, \\
& A_{i}=\int_{0}^{T} \phi_{1}\left(i, G_{1}, \overline{G_{1}}\right)\left|G_{1}(i)-\overline{G_{1}}(i)\right| d i,
\end{aligned}
$$

where $\phi_{1}\left(i, G_{1}, \overline{G_{1}}\right)$ - weight function, which shows that the same deviations at different points in time are not the same.

Criteria for system efficiency of works and implementation of relevant transport infrastructure projects are defined by expression:

$$
E_{c}=\max \left\{R_{a}, P_{w}\right\} \Lambda \max \left\{C_{a}, M_{o}, K_{e}, S_{t m}\right\} \Lambda \max \left\{P_{t p}\right\} \Lambda \min \left\{T, E, C_{m}, C_{e}, C, L_{j s}\right\},
$$

where $R_{a}$ - return on assets; $P_{w}$ - productivity; $C_{a}$ - capital adequacy; $M_{o}$ - mechanical armament; $K_{e}$ - equipment load factor; $S_{t m}$ - suitability of technical means; $P_{t p}-$ technological process productivity; $T$ - technological process costs; $E$ - energy consumption of the technological process; $C_{m}-$ material costs; $C_{e}-\operatorname{cost}$ of equipment; $C$ - cost of operation of technological processes; $L_{j s}$ - level of job specialization.

Quality control is a mandatory element in order to achieve the planned quality indicators of the project in the process of its provision. Which on the basis of intermediate observations of project results makes it possible to determine compliance with regulations and standards and to develop actions to eliminate deviations [12-15]. 
Taking into account the system approach of the process, a model of management and decisionmaking support of diagnostics of technical means in transport infrastructure projects has been developed. Due to the functional and information communication and information exchange processes between diagnostic procedures, the model is presented in the form of a diagram (Fig. 1). The model itself reflects the mechanism of the intellectual decision support system in assessing the state of technical means $[1,14]$, as well as the prospects of planning and timely maintenance and repair.

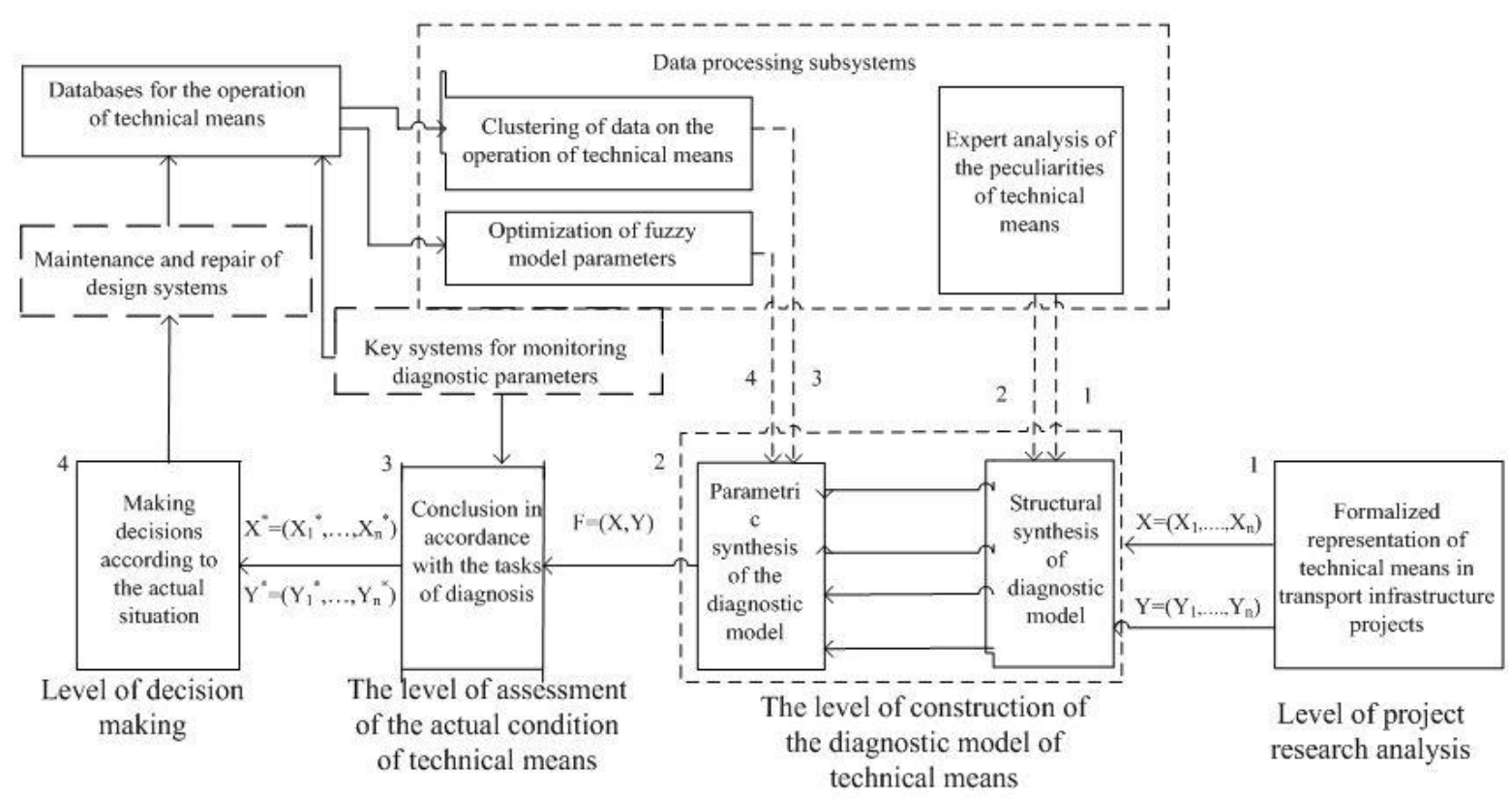

Fig. 1. Model of management and decision support of diagnostics of technical means in transport infrastructure projects

The analysis of the object of transport infrastructure includes the study of structural and functional features of technical means. A list of key parameters that are diagnostic features of subsystems and components of technical means, a set of inspection methods and a list of defective conditions for each type of technical means is needed [6, 7]. Diagnostic assessment of technical means is determined by the classification task:

$$
X=\left(x_{1}, x_{2}, \ldots, x_{n}\right) \rightarrow Y=\left(y_{1}, y_{2}, \ldots, y_{n}\right),
$$

where $X=\left(x_{1}, x_{2}, \ldots, x_{n}\right)$-these are diagnostic parameters of technical means aggregated by the principle of association with its elements and presented in the form of hierarchy; Y many classes of state of technical means connected with algorithms of actions on the investigated object.

The obtained fuzzy model is used to estimate the actual technical condition $\mathrm{Y}^{*}$ depending on the monitoring of data on the parameters $X^{*}$. Recommendations for operation, maintenance and repair work are formed on the basis of diagnostic results and used by engineering and technical personnel at the planning stage.

It is possible to develop recommendations on individual elements, including the analysis and elimination of typical defects, as well as, accordingly, a comprehensive assessment of the state of technical means, which helps to determine further strategies for operation. 
Thus, the proposed control model opens the possibility of interaction between the control subsystem of monitoring and diagnostics and planning of the subsystem of a certain complex based on the actual technical condition. At the same time, monitoring can be performed periodically or on-line.

Conclusions. The problem of quality management of repair and operation of technical means in projects of development and maintenance of transport infrastructure is analyzed. It is determined that it is possible to solve it by improving the quality management system and developing the planning methodology in transport infrastructure projects. The complex of technological tasks and measures which is necessary for maintenance of process of operation of technical means is investigated. The quality assurance process at the level of quality management in transport infrastructure projects consists of the adoption of planned systematic measures to ensure the implementation of all envisaged processes necessary for the project to meet quality requirements. The formation of the quality assurance plan is based on a systematic approach, which became the basis for the development of a management model and support for decision-making diagnostics of technical means in transport infrastructure projects. The paper develops a system model of operation management of technical means of transport, which opens the possibility to determine the system efficiency of development and implementation of relevant transport infrastructure projects, improvement of quality management of repair and maintenance of technical means of transport.

\section{REFERENCES}

1. Kulbovskyi I., Sapronova S., Holub H., Tkachenko V., Afanasieva I., Safronov O. (2019). Development of a model for managing the quality of repair and mainfentenance of rolling stock in transport infrastructure projects. 2019. $23^{\text {rd }}$ international scientific conference TRANSPORT MEANS 2019, 2, 201-205.

2. Blokhin, L.M., \& Burichenko, M.Yu. (2003). Statychna dynamiky system upravlinnya [Static dynamics of control systems]. Kyiv: National Aviation University [in Ukrainian].

3. Levkovets, P.R., Gedz, Y.M., \& Kanarchuk, O.V. (2002). Systemna efektyvnist' na transporti. Metody, modeli i statehiyi [Static dynamics of control systems]. Kyiv: National transport University [in Ukrainian].

4. Gorbachev, P.F., \& Dmitriev, I.A. (2002). Osnovy teorii transportnykh sistem [undamentals of the theory of transport systems]. Kharkiv: KhNADU [in Russian].

5. Melnychenko, O.I., Kulbovskiy, I.I., \& Shestak, V.G. (2010). Pryntsypy otsinky investytsiynykh proektiv koliynoho hospodarstva metropolitenu [Principles of evaluation of metro track investment projects.]. Zbirnyk naukovykh prats' «Transportni systemy i tekhnolohiyi» DETUT - Collection of scientific works «Transport systems and technologies» DETUT, 16, 232-240 [in Ukrainian].

6. Melnychenko, O.I., \& Kulbovskiy, I.I. (2011). Rozrobka stratehiy vykorystannya vyrobnycho-tekhnolohichnoho potentsialu pidrozdiliv koliynoho hospodarstva metropoliteniv [Development of strategies for the use of production and technological potential of subway railway subdivisions]. Upravlinnya proektamy, systemnyy analiz $i$ lohistyka - Project management, systems analysis and logistics, 8, 146-150 [in Ukrainian].

7. Rukovodstvo k svodu znaniy po upravleniyu proyektami (Rukovodstvo RMVOK) [Guide to the Project Management Body of Knowledge (PMBOK Guidelines]. (2010). Amerikanskiy natsional'nyy standart: ANSI/PMI 99-]001-CШA: Project Management Institute [in Russian].

8. Bushuyev, S.D., Bushuyeva, N.S., Babayev, I.A., Yakovenko V.B., et al. (2010). Kreativnyye tekhnologii upravleniya proyektami i programmami [Creative technologies for project and program management]. Kiev: Summit-Book [in Russian].

9. Melnychenko, O.I., Kulbovskiy, I.I., \& Kishka S.P. (2014). Formuvannya systemnoho pidkhodu do upravlinnya proektamy v protsesi ekspluatatsiyi tekhninykh zasobiv [Formation of a systematic approach to project management in the process of operation of technical means]. Zbirnyk naukovykh prats" «Transportni systemy i tekhnolohiyi» DETUT - Collection of scientific works «Transport systems and technologies» DETUT, 24, 28-31 [in Ukrainian].

10. Kulbovskyi I., Sapronova, S., Holub, H., Tkachenko, V., \& Musorina, M. (2019). Modeling of Management Strategies for Manufacturing Technological Processes in Metro Power Supply Projects. TRANSBALTICA 2021: TRANSBALTICA XI: Transportation Science and Technology, 211-219.

11. Babayev, V.M. Upravlinnya proektamy: Navchal'nyy posibnyk dlya studentiv spetsial'nosti «Upravlinnya proektamy» [Project Management: Textbook for students majoring in «Project Management»]. Kharkiv: KNAMG [in Ukrainian]. 
12. Kulbovskyi, I., Holub, H., Skliarenko, I., Honnoshyna, I., Klochkov, Yu., \& Kharuta, Val. (2019). Research on the possibilities of solution of the monitoring projects of railway power supply system. Technology Audit and production reserves, 6/2 (50), 13-15. DOI: 10.15587/2312-8372.2019.187278

13. Sytnik, V.F., \& Karagadova, Je.A.: Mathematical models in planning and managing the enterprise (1985). K. $214 \mathrm{p}$.

14. Melnychenko, O.I., Kulbovskiy, I.I., Holub, H., \& Kharuta, V. (2020) Aspekty metrolohichnoho zabezpechennya tekhnolohichnykh protsesiv informatsiyno-vymiryuval'nykh system $\mathrm{v}$ proektakh infrastruktury transportu [Aspects of metrological support of technological processes of information and measuring systems in transport infrastructure projects]. Visnyk Natsional'noho transportnoho universytetu: Tekhnichni nauky - Bulletin of the National Transport University: Technical Sciences, 1 (46), 226-235 [in Ukrainian].

15. Vasylevs'ka, A. (2012). Upravlinnya proektamy pidpryyemstva iz vykorystannyam informatsiynykh tekhnolohiy [Project management of the enterprise with the use of information technologies]. Visnyk KNTEU - Bulletin KNTEU, 1, 99105 [in Ukrainian].

\section{Іван Кульбовський ${ }^{1}$ Галина Голуб ${ }^{2 *}$, Віктор Меленчук ${ }^{3}$, Віктор Чмир}

${ }^{1}$ Кафедра автоматизації та комп’ютерно-інтегрованих технологій транспорту, Державний університет інфраструктури та технологій, вул. Кирилівська, 9, м. Київ, 04071, Україна

${ }^{2}$ Кафедра автоматизації та комп'ютерно-інтегрованих технологій транспорту, Державний університет інфраструктури та технологій, вул. Кирилівська, 9, м. Київ, 04071, Україна

${ }^{3}$ Кафедра ремонту та експлуатації автомобільної та спеціальної техніки, Військова академія, вул. Фонтанська дорога, 10, м. Одеса, 65009, Україна

4 Кафедра транспортних засобів та спеціальної техніки, Національна академія Державної прикордонної служби України імені Богдана Хмельницького, вул. Шевченка, 46, м. Хмельницький, 29000, Україна

*Corresponding author: golub_gm@gsuite.duit.edu.ua

\section{РОЗРОБКА СИСТЕМНОЇ МОДЕЛІ УПРАВЛІННЯ ЕКСПЛУАТАЦІЮЮ ТЕХНІЧНИМИ ЗАСОБАМИ В ПРОЕКТАХ ІНФРАСТРУКТУРИ ТРАНСПОРТУ}

У статті розглянуто проблеми управління якістю ремонту та експлуатації технічних засобів в проєктах розвитку та підтримки інфраструктури транспорту, щзо $\epsilon$ найважливішим чинником підвищення рівня життя, економічної, соиіальної й екологічної безеки. Розглянуто систему управління якістю проекту та методологію планування. Досліджено, щзо для вдосконалення даної системи необхідно вирішити проблему інтеграції принципів управління якістю та їх адаптацію до проєктів інфраструктури транспорту $з$ управління якістю ремонту та експлуатації технічних засобів та показано шляхи вирішення.

Розглянуто комплекс взаємопов'язаних організачійно технологічних завдань $i$ заходів, які спрямовані на відновлення нормативних транспортно-експлуатаційних показників ремонту та експлуатації технічних засобів транспорту.

Досліджено, шуо процес забезпечення якості проєкту на рівні управління якістю в проєктах інфраструктури транспорту складається з прийняття планових систематичних заходів, щзо забезпечують виконання усіх передбачених прочесів. На основі досліджень запропоновано системну модель критеріїв за допомогою якої можна визначити системну ефективність розробки та реалізації відповідних проєктів інфраструктури транспорту.

У результаті вирішення поставленої проблеми розроблено модель управління та підтримки прийняття рішень діагностики технічних засобів в проєктах інфраструктури транспорту, яка відкриває перспективи планування $i$ своєчасного технічного обслуговування та ремонту технічних засобів транспорту для забезпечення та підвищення безпеки руху.

Ключові слова: технічні засоби, модель, система управління, моніторинг, проєкт, якість, системний аналіз. 